\title{
WEWENANG KEJAKSAAN SEBAGAI PEMOHON PAILIT UNTUK KEPENTINGAN NEGARA TERHADAP UTANG PAJAK SUBYEK HUKUM DARI NEGARA ANGGOTA ASEAN NON-INDONESIA PASCA BERLAKUNYA AEC
}

(The Authority of Prosecutors as Bankruptcy Applicant on Behalf of State Interest towards Tax Debt of Foreign ASEAN Non-Indonesian Legal Subjects after AEC Entered Into Force)

\author{
B.G.M. Widipradnyana Arjaya \\ Kejaksaan Agung Republik Indonesia \\ Email: arjayawidipradnyana@yahoo.co.id
}

Naskah diterima: 11 Juni 2014; revisi: 19 Agustus 2014; disetujui: 22 Agustus 2014

\begin{abstract}
Abstrak
Mulai berlaku efektifnya Masyarakat Ekonomi ASEAN atau ASEAN Economic Community diharapkan membawa dampak positif terhadap perekonomian Indonesia, khususnya bidang perpajakan sebagai sumber utama pendapatan negara. Pemerintah berkewajiban untuk mengelola secara maksimal pendapatan pajak yang diperoleh pemerintah Indonesia dari kegiatan ekonomi yang dilakukan oleh subyek hukum negara ASEAN non-Indonesia, salah satunya pengelolaan pendapatan pajak adalah dengan menyelesaikan sengketa utang piutang pajak yang memposisikan negara sebagai Kreditor. Salah satu pilihan penyelesaian sengketa yang dapat digunakan adalah melalui prosedur kepailitan dengan pengajuan permohonan pailit demi kepentingan umum oleh Kejaksaan pada sistem peradilan Indonesia serta melaksanakan pengurusan harta Debitur pailit yang berada di luar Indonesia untuk membayar utang pajak terhadap Kreditor melalui kepailitan lintas batas (cross border insolvency).

Kata Kunci: utang pajak, kepailitan lintas batas, kejaksaan
\end{abstract}

\section{Abstract}

ASEAN Economic Community (AEC) will enter into force in 2015 and expected to bring positive impact on the Indonesian economy, especially in the field of taxation as the main source of state revenue. Government is obliged to manage taxes that earned by Indonesian government from economic activities undertaken by foreign legal in ASEAN area subjects which done in Indonesia maximally, as an example is to resolve tax disputes that positioning Indonesia as a creditor. One of dispute settlement method which could be used through bankruptcy petition filled by prosecutors for the reason of public interest and also conducts management of bankrupt debtor assets which located outside of Indonesia to pay tax debts to creditors through cross-border insolvency.

Keywords: tax debt, cross border insolvency, prosecutor 


\section{A. Pendahuluan}

Cita-cita menjadikan ASEAN sebagai suatu area ekonomi tunggal dalam ASEAN Economic Community (selanjutnya disebut AEC) bukanlah hal yang mudah, negara-negara anggota ASEAN tentu memiliki kepentingan ekonomi yang berbeda-beda. Kepentingan negaranegara ini harus diakomodasikan dalam AEC karena tujuan akhir dari pemerintah negaranegara ASEAN sepakat untuk mengintegrasikan perekonomiannya adalah untuk kesejahteraan masyarakat masing-masing negara. Begitu pula dengan ikut sertanya Indonesia sebagai anggota ASEAN dalam AEC sedikit banyaknya tentu bermuatan kepentingan untuk meningkatkan kesejahteraan rakyat Indonesia. Jangan sampai Indonesia hanya menjadi pasar yang rakyatnya hanya berperan sebagai konsumen belaka tanpa mampu ikut menikmati perputaran mata uang dalam area AEC.

Salah satu sumber pendapatan terbesar Indonesia yang juga terdapat pengaturannya dalam AEC blueprint sebagai pedoman mewujudkan integrasi ekonomi ASEAN adalah dalam hal perpajakan. APBD Indonesia dari tahun ke tahun menempatkan pajak sebagai sumber pendapatan utama untuk menjalankan roda perekonomian nasional Indonesia. AEC blueprint hanya memuat ketentuan mengenai perpajakan dalam satu bagian singkat saja, yaitu untuk menyelesaikan jaringan perjanjian bilateral dalam hal pencegahan pengenaan pajak berganda antara seluruh negara anggota ASEAN pada tahun 2010.

Sebagai sumber utama pendapatan negara $^{1}$ pemerintah Indonesia dengan segenap aparaturnya harus memastikan bahwa pemberlakuan AEC tidak akan berpengaruh negatif terhadap pendapatan Indonesia dari sektor perpajakan, malah dengan berlakunya AEC justru Indonesia harus dapat menggali potensi pajak dari sektor-sektor perekonomian lain seperti penanaman modal asing, perdagangan, maupun jasa dari pihak asing yang melakukan kegiatan ekonomi di dalam yurisdiksi pemerintah Indonesia.

Salah satu upaya untuk melindungi pendapatan negara dalam bidang perpajakan adalah dengan cara menyelesaikan sengketa yang menempatkan negara sebagai pihak yang memiliki piutang pajak yang tidak dibayarkan oleh Debitur subyek hukum asing. Penindakan terhadap sengketa perpajakan yang menempatkan negara sebagai pihak Kreditor biasanya dilakukan menurut prosedur hukum administrasi dengan menerapkan denda. Sanksi administrasi ini sebagaimana kita ketahui bersama kurang diindahkan oleh pihak-pihak yang berkewajiban untuk membayar pajak sehingga negara berpotensi menanggung kerugian yang jumlahnya tak sedikit.

Selain sanksiadministrasi regulasi perpajakan Indonesia juga telah mengatur mengenai pidana perpajakan terhadap pihak-pihak yang dengan sengaja melakukan penggelapan pajak, namun penerapan sanksi pidana dalam lingkup bisnis antar negara tentu beresiko terhadap kesinambungan kegiatan ekonomi asing di Indonesia. Sanksi pidana adalah hal yang sangat tidak popular dan sangat dihindari oleh pelaku bisnis asing, pengenaan sanksi pidana terhadap pihak asing akan menyebabkan pelaku bisnis

Pasal 4 ayat (1) jo Pasal 3, Undang-Undang Nomor 23 Tahun 2013 tentang Anggaran Pendapatan dan Belanja Negara Tahun Anggaran 2014. 
akan menarik diri dari kegiatan ekonomi yang sebelumnya dilakukan di Indonesia.

$\mathrm{Di}$ luar proses penyelesaian sengketa perpajakan yang diatur dalam regulasi pajak dalam hukum positif Indonesia terdapat satu opsi yang berlaku terhadap penyelesaian utang secara umum, yaitu melalui prosedur acara kepailitan. Pengajuan permohonan pailit terhadap utang pajak dapat ditempuh dua opsi, kantor pajak dapat memberikan kuasa kepada suatu kantor hukum tertentu atau dapat menyerahkan kasus tersebut kepada Kejaksaan Agung agar Kejaksaan Agung dapat bertindak sebagai pemohon pailit untuk kepentingan umum.

Di bidang perdata dan tata usaha negara Kejaksaan dengan kuasa khusus dapat bertindak di dalam dan luar persidangan mewakili negara ${ }^{2}$, kewenangan ini kemudian melahirkan istilah Jaksa Pengacara Negara. Di era reformasi nama jaksa pengacara Negara mulai terdengar gaungnya saat era Jaksa Agung Abdul Rahman Saleh. Kala itu Kejaksaan agung setelah menghentikan penuntutan perkara pidana mantan presiden Soeharto yang ditandai dengan dikeluarkannya Surat Ketetapan Penghentian Penuntuan Perkara (SKPPP) memutuskan untuk mengejar kerugian Negara yang ditimbulkan Soeharto melalui Yayasan Supersemar pada era orde baru dengan gugat keperdataan, dalam hal ini adalah gugatan perbuatan melanggar hukum (onrechtmatigedaad) ${ }^{3}$.

Wewenang Kejaksaan yang lebih khusus di bidang perdata, yaitu dalam kepailitan diatur dalam Undang-Undang Nomor 37 Tahun 2004 tentang Kepailitan dan Penundaan Kewajiban Pembayaran Utang dalam Pasal 2 ayat (2) dimana Kejaksaan berwenang untuk memohon pailit demi kepentingan umum. Salah satu definisi dari kepentingan umum menurut penjelasan Pasal ini adalah kepentingan bangsa dan negara. Dengan mulai efektif diberlakukannya AEC pada tahun 2015, Kejaksaan sebagai lembaga yang diberi kewenangan untuk mengajukan permohonan pailit untuk kepentingan negara diharapkan untuk dapat melindungi kepentingan piutang pajak negara melalui kepailitan, dan kepentingan negara lain yang menempatkan negara sebagai Kreditor yang memiliki piutang dalam kepailitan.

Berdasarkan latar belakang tersebut di atas, maka penulis mengangkat permasalahan apakah utang pajak subyek hukum asing dapat dikategorikan sebagai utang dalam hukum kepailitan Indonesia?, dan apakah Kejaksaan berwenang memohonkan pailit untuk kepentingan umum terhadap utang pajak subyek hukum negara ASEAN non-Indonesia?

\section{B. Metode penelitian}

Metode penelitian yang digunakan dalam penulisan ini adalah metode penelitian normatif dengan pendekatan perundang-undangan (statute approach) dan pendekatan konsep (conceptual approach). Bahan hukum yang digunakan adalah bahan hukum yang diperoleh melalui buku kepustakaan, artikel, peraturan perundang-undangan, jurnal ilmiah serta situs internet.

Pasal 30 ayat (2), Undang-Undang Nomor 16 Tahun 2004 tentang Kejaksaan Republik Indonesia.

Abdul Rahman Saleh, Bukan Kampung Maling, Bukan Desa Ustadz, (Jakarta: Kompas Media Nusantara, 2008), hlm. 213-214. 


\section{Pembahasan}

1. Kepailitan sebagai penyelesaian sengketa utang pajak oleh subyek hukum dari negara ASEAN nonIndonesia pasca berlakunya AEC

\section{a. Keberadaan Utang Pajak dalam Domain AEC}

ASEAN Economy Community (selanjutnya disebut $A E C$ ) adalah pelaksanaan dari tujuan akhir integrasi ekonomi sebagaimana dianut dalam Vision 2020 yang berdasarkan kepada kesamaan kepentingan Negara-negara anggota ASEAN yang ingin memperdalam dan juga memperlebar integrasi ekonomi melalui inisiatif-inisiatif baru maupun yang telah ada dalam suatu kalender kegiatan yang jelas.

Para pemimpin Negara-negara ASEAN guna mewujudkan cita-cita integrasi ekonomi dalam lingkup ASEAN melalui AEC memformulasikan suatu kesepakatan multilateral yang memuat tujuan dari AEC serta langkah-langkah yang harus dilakukan guna merealisasikan tujuan-tujuan tersebut. Kesepakatan yang merupakan hasil perundingan dari pemimpin-pemimpin Negara ASEAN tersebut dinamakan ASEAN Economic Community Blueprint ${ }^{4}$ (selanjutnya disebut AEC Blueprint). AEC Blueprint merupakan pedoman bagi Negara-negara anggota ASEAN untuk mencapai AEC 2015, dimana masing-masing Negara berkewajiban untuk melaksanakan komitmen dalam blueprint tersebut. AEC Blueprint memuat empat kerangka utama ${ }^{5}$, yaitu :
1) ASEAN sebagai pasar tunggal dan basis produksi internasional dengan elemen aliran bebas barang, jasa, investasi, tenaga kerja terdidik dan aliran modal yang lebih bebas;

2) ASEAN sebagai kawasan dengan daya saing ekonomi yang tinggi, dengan elemen peraturan kompetisi, perlindungan konsumen, hak atas kekayaan intelektual, pengembangan infrastruktur, perpajakan, dan e-commerce;

3) ASEAN sebagai kawasan dengan pengembangan ekonomi yang merata dengan elemen pengembangan usaha kecil dan menengah dan prakarsa integrasi ASEAN untuk Negara-negara CMLV (Cambodia, Myanmar, Laos, dan Vietnam); dan

4) ASEAN sebagai kawasan yang terintegrasi secara penuh dengan perekonomian global dengan elemen pendekatan yang koheren dalam hubungan ekonomi di luar kawasan, dan meningkatkan peran serta dalam jejaring produksi global.

Integrasi ekonomi dalam Lingkup AEC berefek terjadinya liberalisasi perdagangan barang, jasa, investasi, perpindahan tenaga kerja terampil dan arus modal yang lebih bebas. Liberalisasi ekonomi ini tentu akan bersinggungan dengan kepentingan nasional para Negara anggota sebagai Negara yang berdaulat. Untuk itu AEC juga harus diimbangi dengan perjanjian bilateral lain antar Negara anggota untuk mengkompromikan kepentingan ASEAN sebagai suatu perhimpunan regional

ASEAN Secretariat, "ASEAN Economic Community Blueprint", (Jakarta, 2008), www.asean.org/archive/5187-10. pdf (diakses 9 Mei 2014).

Departemen Perdagangan Republik Indonesia, "Menuju ASEAN Economic Community 2015", http:// ditjenkpi.kemendag.go.id/website_kpi/Umum/Setditjen/Buku\%20Menuju\%20ASEAN\%20ECONOMIC\%20 COMMUNITY\%202015.pdf (diakses 9 Mei 2014) 


\section{RUECHTSVINDING}

Media Pembinaan Hukum Nasional

dengan kepentingan nasional Negara yang menyangkut harkat hidup warga dari negara tersebut.

Salah satu kepentingan Negara yang sepatutnya didahulukan dalam era liberalisasi ekonomi yang timbul dengan berlakunya AEC adalah pajak. Hukum positif Indonesia yaitu Undang Undang Nomor 8 Tahun 1983 tentang Ketentuan Umum dan Tata Cara Perpajakan sebagaimana perubahan terakhir dalam Undang-Undang Nomor 28 Tahun 2007 (selanjutnya disebut UUKUP) mendefinisikan pajak sebagai kontribusi wajib kepada Negara yang terutang oleh orang pribadi atau badan yang bersifat memaksa berdasarkan undangundang, dengan tidak mendapatkan imbalan secara langsung dan digunakan untuk keperluan Negara bagi sebesar-besarnya kemakmuran rakyat. Keberadaan pajak sebagai elemen penting dalam penyelenggaraan negara dapat dilihat dari Undang-undang APBN Indonesia yang dari tahun ke tahun memperlihatkan keberadaan pajak sebagai sumber pendapatan negara yang utama.Sebagai sumber utama pendapatan negara tentu Indonesia harus memberikan perhatian serius terhadap pengenaan pajak yang dapat diberlakukan dalam lingkup AEC terhadap subyek hukum negara-negara ASEAN yang melakukan kegiatan ekonomi dalam yurisdiksi Indonesia.

Pengenaan pajak di Indonesia tidak terbatas hanya kepada orang perseorangan (persoon) tetapi juga terhadap badan hukum (rechtpersoon), dapat dilihat dari ketentuan dalam Pasal 1 angka 2 UUKUP yang menyatakan bahwa wajib pajak adalah orang pribadi atau badan, dilanjutkan dengan Pasal 1 angka 3 UUKUP mengenai definisi badan sebagai sekumpulan orang dan/atau modal yang merupakan kesatuan baik yang melakukan
Volume 3 Nomor 2, Agustus 2014

usaha maupun yang tidak melakukan usaha yang meliputi perseroan terbatas, perseroan komanditer, perseroan lainnya, badan usaha milik negara atau badan usaha milik daerah dengan nama dan dalam bentuk apa pun, firma, kongsi, koperasi, dana pensiun, persekutuan, perkumpulan, yayasan, organisasi massa, organisasi sosial politik, atau organisasi lainnya, lembaga dan bentuk badan lainnya termasuk kontrak investasi kolektif dan bentuk usaha tetap. Penggolongan wajib pajak berdasarkan orang pribadi dan badan menyimpulkan bahwa subyek hukum asing baik perseorangan maupun badan hukum menurut ketentuan perpajakan Indonesia dapat dikenakan kewajiban untuk membayar pajak apabila melakukan kegiatan usahanya di Indonesia.

Secara khusus AEC Blueprint membahas mengenai pajak dalam bagian B5 pada poin ke 58 I. yang menyatakan "Complete the network of bilateral agreements on avoidance of double taxation among all Member Countries by 2010, to the extent possible." Selain pengaturan secara khusus AEC Blueprint juga menyinggung beberapa hal tentang perpajakan, antara lain membangun jaringan efektif perjanjian bilateral untuk pencegahan pengenaan pajak ganda antar Negara-negara ASEAN sebagai tindakan untuk mempromosikan ASEAN sebagai area investasi dan jaringan produksi terintegrasi, untuk memperkuat pengembangan dan pengintegrasian pasar modal ASEAN dengan cara menambah struktur pengurangan pajak jika dimungkinkan untuk mempromosikan perluasan basis investor dalam pemberian utang di ASEAN.

MeskidalamAECBlueprint porsipembahasan mengenai perpajakan sangat singkat tetapi hampir segala kegiatan usaha dalam zona AEC yang dilakukan pada teritorial Indonesia dapat 
dikenakan pajak oleh pemerintah Indonesia. Mulai dari kegiatan jual beli sederhana, investasi, perdagangan jasa dan profesi, sampai hak kekayaan intelektual, selama kegiatan-kegiatan tersebut berlansung dalam yurisdiksi Indonesia pemerintah Indonesia berhak untuk memungut pajak. Terkecuali kegiatan-kegiatan yang telah disepakati pajaknya dipungut oleh negara asal dalam suatu perjanjian bilateral antar negara dalam hal pencegahan pajak berganda (double taxation avoidance agreement).

Sampai saat ini Indonesia telah menandatangani perjanjian pencegahan pengenaan pajak berganda dengan 59 Negara di dunia. Di tingkat ASEAN Indonesia telah menyepakati perjanjian pencegahan pengenaan pajak ganda (double taxation avoidance agreement) dengan beberapa negara anggota ASEAN lainnya. Sampai saat ini perjanjian bilateral yang telah disepakati antara Republik Indonesia dengan anggota ASEAN lainnya berjumlah enam perjanjian ${ }^{6}$ yang sudah berlaku efektif antara lain dengan negara Malaysia, Brunei Darussalam, Singapura, Thailand, Filipina, dan Vietnam.

Dalam lingkup penyelesaian sengketa pajak Indonesia memiliki regulasi dalam hal peradilan pajak yaitu UU Pengadilan Pajak, Nomor 14 Tahun 2002, akan tetapi substansi dari undangundang ini lebih condong kepada penyelesaian sengketa perpajakan dalam hal timbulnya sengketa yang diakibatkan pelaksanaan penagihan pajak dan keputusan yang dapat diajukan banding atau gugatan, dengan kata lain gugatan pada pengadilan pajak hanya berlaku searah dari wajib pajak atau penanggung pajak kepada pejabat yang berwenang. UndangUndang Pengadilan Pajak merupakan satusatunya legislasi perpajakan yang berada dalam domain hukum perdata, namun sayangnya ketentuan acara undang-undang tersebut hanya berlaku searah. Selain undang-undang tersebut penyelesaian sengketa pajak yang terjadi masuk ke dalam ranah hukum pidana dan hukum administrasi.

Secara pidana Penyelesaian sengketa pajak yang timbul akibat tidak dibayarkannya utang pajak dari wajib pajak kepada pejabat yang berwenang diatur dalam undang-undang ketentuan umum dan tata cara perpajakan dalam Pasal 39 ayat (1) huruf I UUKUP yang menyatakan bahwa Wajib pajak yang tidak menyetorkan pajak yang telah dipotong atau dipungut, sehingga dapat menimbulkan kerugian pada pendapatan Negara dipidana dengan pidana penjara paling singkat 6 (enam) bulan dan paling lama 6 (enam) tahun dan denda paling sedikit 2 (dua) kali jumlah pajak terutang yang tidak atau kurang dibayar dan paling banyak 4 (empat) kali jumlah pajak terutang yang tidak atau kurang dibayar.

Pemrosesan tindak pidana perpajakan dapat dihentikan dengan ketentuan yang diatur dalam ketentuan Pasal-Pasaldalam UUKUP berikut :

- Pasal 44B ayat (1), untuk kepentingan penerimaan Negara, atas permintaan menteri keuangan, jaksa agung dapat menghentikan penyidikan tindak pidana di bidang perpajakan paling lama dalam jangka waktu 6 (enam) bulan sejak tanggal surat permintaan.

Badan Koordinasi Penanaman Modal, "Avoidance of Double Taxation Agreement", http://www3.bkpm.go.id/ contents/p14/taxation/14\#.U5fE9PI_tQF (diakses 10 Juni 2014). 
- Pasal 44B ayat (2), penghentian penyidikan tindak pidana di bidang perpajakan sebagaimana dimaksud pada ayat (1) hanya dilakukan setelah wajib pajak melunasi utang pajak yang tidak atau kurang dibayar atau yang tidak seharusnya dikembalikan dan ditambah dengan sanksi administrasi berupa denda sebesar 4 (empat) kali jumlah pajak yang tidak atau kurang dibayar, atau yang tidak seharusnya dikembalikan.

Selain dengan pengenaan ketentuan pidana perpajakan masih ada satu opsi penyelesaian sengketa perpajakan yang dapat diambil, penyelesaian ini berada di luar peraturan perundang-undangan perpajakan Indonesia, yaitu dengan prosedur kepailitan.

\section{b. Kedudukan Utang Pajak Menurut Utang Dalam Kepailitan}

Pengenaan sanksi pidana terhadap wajib pajak perorangan maupun badan hukum asing akan berimbas terhadap kegiatan usaha dari pihak asing tersebut di Indonesia, hal ini akan ikut memberi efek negatif terhadap perekonomian Indonesia sebagai lokasi subyek hukum asing tersebut melakukan kegiatan ekonomi, selain itu juga akan menimbulkan keraguan warga negara atau badan hukum asing lainnya yang berminat untuk melakukan kegiatan usaha di Indonesia untuk menghindari kemungkinan dikenakannya sanksi pidana pada saat melakukan kegiatan usaha.

Penggunaan prosedur kepailitan sebagai penyelesaian sengketa utang piutang pajak yang tak dibayarkan oleh wajib pajak kepada negara lebih ramah terhadap Debitur dan dapat menjaga stabilitas iklim investasi di
Indonesia yang lebih kondusif dibanding dengan menerapkan aturan pidana dalam regulasi perpajakan Indonesia. Pengertian kepailitan menurut Pasal 1 angka 1 Undang-Undang Nomor 37 Tahun 2004 tentang Kepailitan dan Penundaan Kewajiban Pembayaran Utang (selanjutnya disebut UUKPKPU) adalah "sita umum atas semua kekayaan Debitur pailit yang pengurusan dan pemberesannya dilakukan oleh Kurator di bawah pengawasan Hakim pengawas. Untuk dapat memohon pailit dalam sistem acara peradilan di Indonesia diperlukan tiga faktor yaitu adanya Debitur, minimal dua orang Kreditor, adanya utang dari Debitur terhadap Kreditor tersebut dengan ketentuan sedikitnya satu utang yang telah jatuh waktu dan dapat ditagih belum dibayar lunas. Adapun orang dalam hukum kepailitan tak terbatas hanya pada orang perseorangan tetapi juga korporasi yang berbentuk badan hukum maupun yang bukan badan hukum dalam likuidasi, maka subyek hukum baik orang perseorangan maupun badan hukum asing yang memiliki utang pajak termasuk sebagai pengertian orang dalam hukum kepailitan Indonesia.

Utang adalah titik permulaan dari serangkaian prosedur acara kepailitan. Permohonan pailit beranjak dari sengketa yang timbul akibat Debitur yang tidak membayar utangnya. Sebagaimana pendapat Hadi Shubhan, Utang merupakan raison d'etre dari kepailitan. ${ }^{7}$ Dalam UUKPKPU definisi utang diatur dalam Pasal 1 angka 6 UUKPKPU yaitu suatu kewajiban yang dinyatakan atau dapat dinyatakan dalam jumlah uang baik dalam mata uang Indonesia maupun mata uang asing, baik secara langsung maupun yang akan timbul

Hadi Shubhan, Hukum Kepailitan, Prinsip, Norma, dan Praktik di Pengadilan (Jakarta: Kencana, 2009), hlm. 92. 
di kemudian hari atau kontinjen, yang timbul karena perjanjian atau undang-undang dan yang wajib dipenuhi Debitur dan bila tidak dipenuhi memberi hak kepada Kreditor untuk mendapat pemenuhannya dari harta kekayaan Debitur.

Jika menguraikan unsur-unsur dalam definisi utang pada redaksi Pasal 1 angka 6 UUKPKPU maka kesesuaian utang pajak sebagai utang dalam kepailitan adalah sebagai berikut:

- kewajiban yang dinyatakan atau dapat dinyatakan dalam jumlah uang baik dalam mata uang Indonesia maupun mata uang asing: kewajiban pajak dinyatakan dalam jumlah mata uang rupiah yang harus dibayarkan yang dicantumkan dalam suatu surat ketetapan pajak atau surat sejenisnya;

- baik secara langsung maupun yang akan timbul dikemudian hari atau kontinjen: utang pajak terjadi secara terus menerus (kontinjen) setiap tahun dengan ketentuan bahwa tahun pajak mengikuti tahun kalender kecuali apabila wajib pajak menggunakan tahun buku yang tidak sama dengan tahun kalender;

- yang timbul karena perjanjian atau undangundang dan yang wajib dipenuhi Debitur: pajak timbul karena diatur oleh pemerintah dalam kumpulan perundang-undang perpajakan dan pajak wajib dipenuhi oleh Debitur sebagaimana sifat memaksa dari pajak sebagai kontribusi wajib kepada negara;

- dan bila tidak dipenuhi memberi hak kepada Kreditor untuk mendapat pemenuhannya dari harta kekayaan Debitur: dalam UndangUndang Penagihan Pajak dengan Surat Paksa
Nomor 19 Tahun 1997 dan perubahannya dalam Undang-Undang Nomor 19 Tahun 2000 dikenal adanya penjualan secara lelang apabila utang pajak dan/ atau biaya penagihan pajak tidak dilunasi setelah dilaksanakan penyitaan.

Keberadaan utang sangatlah fundamental untuk dapat mengajukan permohonan pailit, hal ini dapat dilihat dari rumusan Pasal 8 ayat 4 UUKPKPU yang menyatakan "permohonan pernyataan pailit harus dikabulkan apabila terdapat fakta atau keadaan yang terbukti secara sederhana bahwa persyaratan untuk dinyatakan pailit sebagaimana dimaksud dalam Pasal 2 ayat (1) telah terbukti.". Adapun persyaratan yang dimaksud untuk mengabulkan permohonan pernyataan pailit terhadap Debituradalah dibutuhkan dua utang dari Debitur kepada Kreditor dimana salah satu dari utang tersebut belum dibayar lunas saat telah jatuh waktu dan dapat ditagih.

Untuk dapat dinyatakan pailit diperlukan minimal satu utang yang telah jatuh waktu dan dapat ditagih yang tidak dibayar lunas dari dua Kreditor, maksud dari ditegaskannya bahwa utang dalam kepailitan merupakan utang yang tidak dibayar lunas adalah untuk memastikan bahwa utang yang telah dibayar akan tetapi belum melunasi kewajiban maka utang tersebut bisa dijadikan dasar untuk mengajukan kepailitan. Penegasan ini karena sering terjadi akal-akalan dari Debitur, yakni, Debitur tetap melakukan pembayaran akan tetapi besarnya angsuran pembayaran tersebut masih jauh dari yang seharusnya. ${ }^{8}$

$8 \quad$ Ibid. 
Utang pajak timbul karena adanya hubungan hukum Utang pajak terhadap negara yang timbul dari undang-undang mengakibatkan kantor pajak berada dalam posisi sebagai Kreditor, dalam kepailitan Indonesia dikenal tiga Kreditor ${ }^{9}$ yaitu:

1) Kreditor konkuren;

2) Kreditor separatis, yaitu Kreditor dengan jaminan kebendaan, berupa gadai, hipotek, hak atas panenan, hak tanggungan, dan jaminan fidusia (tanpa kehilangan hak untuk menjual dan memperoleh pelunasan terlebih dahulu dari harta kebendaan Debitur, yang dijaminkan secara kebendaan dan dijual tersebut);

3) Kreditor preferen dengan hak istimewa menurut Pasal 1139 dan Pasal 1149 KUHPERDATA (tanpa kehilangan hak yang diberikan kepada mereka untuk menahan kebendaan milik Debitur yang diberikan oleh undang-undang).

Utang pajak termasuk dalam golongan Kreditor preferen, Pasal 1134 KUHPERDATA memberikan pengecualian untuk hak istimewa yang oleh undang-undang harus didahulukan daripada hak Gadai dan Hipotek, dalam peraturan perpajakan Indonesia hak istimewa ini diatur dalam Pasal 21 UU KUP ditetapkan bahwa kedudukan negara sebagai Kreditor preferen yang mempunyai hak mendahului atas barang-barang milik penanggung pajak di muka umum guna menutupi atau melunasi utang pajak.

\section{c. Keberlakuan Hukum Kepailitan Indonesia terhadap Debitur Asing}

Mengenai kedudukan Debitur subyek hukum asing yang berdomisili di luar yurisdiksi Indonesia tetap dapat dimohonkan pailit dalam peradilan Indonesia karena kedudukan Debitur yang menjalan usaha dalam teritorial Indonesia menyebabkan berlakunya ketentuan Pasal 3 ayat (4) UUKPKPU yang menyatakan bahwa dalam hal Debitur tidak berkedudukan di wilayah Negara republik Indonesia tetapi menjalankan profesi atau usahanya di wilayah Negara republik Indonesia, pengadilan yang berwenang memutuskan adalah pengadilan yang daerah hukumnya meliputi tempat kedudukan atau kantor pusat Debitur menjalankan profesi atau usahanya di wilayah Negara republik Indonesia.

Dikarenakan Debitur menjalankan usahanya di wilayah Negara Republik Indonesia, maka secara otomatis UUKPKPU berlaku apabila terjadi sengketa kepailitan, meski salah satu pihak baik Kreditor dan Debitur bukanlah warga Negara Indonesia. Konsep kedaulatanteritorial berlaku dalam hal ini, konsep kedaulata teritorial ${ }^{10}$ menandakan bahwa di dalam wilayah kekuasaan negara yurisdiksi dilaksanakan oleh negara terhadap orang-orang dan harta benda yang menyampingkan negara-negara lain.

Lihat Ibid, hlm. 77, dikutip dari Kartini Muljadi, "Kreditor Preferen dan Kreditor Separatis dalam Kepailitan" (2004), hlm. 174-175.

10 J.G. Starke (diterjemahkan oleh Bambang Iriana Djajaatmaja), Pengantar Hukum Internasional 1, (Jakarta: Sinar Grafika, 2010), hlm. 210 
2. Permohonan Pailit oleh Kejaksaan Terhadap Debitur Subyek Hukum dari Negara Anggota ASEAN Non-Indonesia yang Memiliki Utang Pajak

\section{a. Wewenang Kejaksaan untuk Memohon Pailit}

UUKPKPU mengamanatkan bahwa seorang Kreditor dalam melakukan perbuatan hukum di bidang kepailitan harus diwakili oleh advokat, kecuali terhadap permohonan yang diajukan oleh Kejaksaan, Bank Indonesia, Badan Pengawas Pasar Modal, Menteri Keuangan. Berikut tabel pihak yang berhak memohon pailit terhadap Debitur tertentu beserta dasar hukumnya. di bidang perdata sejatinya bukanlah hal yang baru, wewenang ini sudah dimiliki oleh lembaga Kejaksaan pada masa Hindia Belanda ${ }^{11}$. Secara formil dan materiil wewenang lembaga Kejaksaan tersebut telah ada sejak masa kolonialisme kerajaan belanda dimana saat itu Kejaksaan dikenal dengan nama Openbaar Ministrerie (O.M.). pada saat itu selain memiliki wewenang di bidang pidana O.M. juga memiliki sejumlah kekuasaan dalam bidang hukum perdata antara lain:

1) O.M. dapat mewakili Negara dalam perkara perdata, baik selaku penggugat maupun tergugat berdasarkan s.1922/522 tentang

Tabel 1. Para Pihak dalam Permohonan Pailit

\begin{tabular}{|c|c|c|}
\hline Pemohon & Debitur & Dasar Hukum \\
\hline $\begin{array}{l}\text { Debitur atau Kreditor dengan } \\
\text { memberi kuasa kepada Advokat }\end{array}$ & Perorangan atau badan hukum & $\begin{array}{l}\text { Pasal } 2 \text { ayat (1) UUKPKPU, } \\
\text { Pasal } 7 \text { ayat (1) UUKPKPU }\end{array}$ \\
\hline Kejaksaan & $\begin{array}{l}\text { Perorangan atau badan hukum, untuk } \\
\text { kepentingan umum }\end{array}$ & $\begin{array}{l}\text { Pasal } 2 \text { ayat (2) UUKPKPU jo } \\
\text { Pasal } 2 \text { ayat (1), Pasal } 7 \text { ayat } 2 \\
\text { UUKPKPU }\end{array}$ \\
\hline Bank Indonesia & Bank & $\begin{array}{l}\text { Pasal } 2 \text { ayat (3) UUKPKPU jo } \\
\text { Pasal } 2 \text { ayat (1) UUKPKPU, } \\
\text { Pasal } 7 \text { ayat } 2 \text { UUKPKPU }\end{array}$ \\
\hline Badan Pengawas Pasar Modal & $\begin{array}{l}\text { Perusahaan Efek, Bursa Efek, Lembaga } \\
\text { Miring dan Penjaminan, Lembaga } \\
\text { Penyimpanan dan Penyelesaian }\end{array}$ & $\begin{array}{l}\text { Pasal } 2 \text { ayat (4) UUKPKPU jo } \\
\text { Pasal } 2 \text { ayat (1) UUKPKPU Pasal } \\
7 \text { ayat (2) UUKPKPU }\end{array}$ \\
\hline Menteri Keuangan & $\begin{array}{l}\text { Perusahaan Asuransi, Perusahaan } \\
\text { Reasuransi, Dana Pensiun, Badan Usaha } \\
\text { Milik Negara yang bergerak di bidang } \\
\text { kepentingan publik }\end{array}$ & $\begin{array}{l}\text { Pasal } 2 \text { ayat (5) UUKPKPU jo } \\
\text { Pasal } 2 \text { ayat (1) UUKPKPU, } \\
\text { Pasal } 7 \text { ayat (2) UUKPKPU }\end{array}$ \\
\hline
\end{tabular}

Kejaksaan sebagai salah satu unsur catur wangsa penegak hukum di Indonesia selain memiliki wewenang di bidang pidana juga memilik wewenang di bidang perdata dan juga tata usaha negara. Wewenang Kejaksaan
Vertegenwoordiging van den laande in Rechten ( wakil Negara dalam hukum);

2) Karena jabatannya, O.M. berwenang meminta kepada Hakim untuk menempatkan seseorang di suatu tempat tertentu, rumah

11 Evy Lusia Ekawati, Peranan Jaksa Pengacara Negara dalam Penanganan Perkara Perdata (Yogyakarta: Genta Press, 2013), hlm. 53-55. 
sakit atau sesuatu tempat lain yang layak, karena secara terus menerus berkelakuan buruk, yang tidak mampu untuk mengurus dirinya sendiri atau membahayakan orang lain (Pasal 134, 135, 137 dan 137 a R.O.);

3) O.M. berwenang untuk meminta kepada Hakim agar suatu badan hukum dibubarkan karena melakukan penyimpangan dari anggaran dasarnya yang sah (Pasal 1 butir 6 R.O.);

4) Demi kepentingan umum berwenang untuk mengajukan permintaan kepada Hakim supaya seseorang atau badan hukum dinyatakan pailit (Pasal 1 (2) Undang-Undang Failisemen);

5) O.M. didengar pendapatnya dalam hal seseorang akan merubah atau menambah nama depannya (Pasal 13 dan 14 B.W.);

6) O.M wajib menuntut pembatalan kepada Hakim atas suatu perkawinan sebagaimana termaksud dalam Pasal 27 hingga 34 B.W. (lihat juga Pasal 86 B.W.);

7) O.M. dapat menuntut kepada Hakim agar seseorang bapak atau ibu dibebaskan dari kekuasaannya sebagai orang tua atau ouderlijkkemachtnya (Pasal 319 B.W.);

8) O.M. berwenang untuk melakukan penuntutan kepada pengadilan supaya seseorang dipecat sebagai wali dari anak yang belum dewasa (Pasal 381 B.W.);

9) O.M. dapat memerintahkan Balai Harta Peninggalan untuk mengurus harta benda seseorang (Pasal 468 B.W.);

10)O.M. berwenang untuk mengajukan usul bagi pengangkatan pengurus warisan bilamana pengurus yang telah diangkat meninggal dunia, dan sebagainya (Pasal 983, 985 B.W.);
11)O.M. berwenang mengajukan kasasi demi kepentingan hukum dalam hukum perdata (Pasal 170 butir 1 R.O).

Sejak Indonesia menyatakan merdeka dari kolonialisme belanda telah dirumuskan Undang-Undang dan peraturan perundangundangan lain yang khusus mengatur tentang Kejaksaan yang terus mengalami perubahan mengikuti perkembangan jaman.Regulasi yang saat ini berlaku dan mengatur tentang Kejaksaan adalah Undang-Undang Kejaksaan Nomor 16 Tahun 2004 (selanjutnya disebut UU Kejaksaan). Wewenang jaksa di bidang perdata dan tata usaha Negara dapat ditemukan pada rumusan Pasal 30 ayat (2) UU Kejaksaan yang menyatakan bahwa Kejaksaan dengan suatu kuasa khusus dapat bertindak baik di dalam maupun di luar pengadilan untuk dan atas nama Negara dan atau pemerintah dalam suatu perkara perdata atau tata usaha negara.

Secara lebih terperinci Tugas dan wewenang Kejaksaan di bidang perdata dan tata usaha negara ini diatur dalam Pasal 24 Peraturan Presiden Nomor 38 Tahun 2010 tentang Organisasi dan Tata Kerja Kejaksaan, dimana wewenang Kejaksaan dalam hal perdata dan tata usaha Negara dilaksanakan oleh Jaksa Agung Muda bidang Perdata dan Tata Usaha Negara. Lingkup bidang perdata dan tata usaha Negara yang menjadi wewenang Kejaksaan tersebut meliputi penegakan hukum, bantuan hukum, pertimbangan hukum dan tindakan hukum lain kepada Negara atau pemerintah, meliputi lembaga/badan Negara, lembaga/ instansi pemerintah pusat dan daerah, Badan Usaha Milik Negara/Daerah di bidang perdata dan tata usaha Negara untuk menyelamatkan, memulihkan kekayaan Negara, menegakkan kewibawaan pemerintah dan Negara serta 
memberikan pelayanan hukum kepada masyarakat.

Di bidang keperdataan yang lebih khusus, dalam hal ini kepailitan, Kejaksaan memiliki kewenangan untuk mengajukan permohonan pailit terhadap Debitur yang tidak membayar utangnya kepada pengadilan. Kewenangan untuk mengajukan permohonan pailit ini sudah dimiliki Kejaksaan sejak era kolonial, dibuktikan dengan Wewenang O.M. untuk mengajukan permintaan kepada Hakim Demi kepentingan umum supaya seseorang atau badan hukum dinyatakan pailit dalam Pasal 1 ayat (2) UndangUndang Failisemen. Dalam regulasi Kepailitan yang saat ini berlaku yaitu Undang-Undang Nomor 37 Tahun 2004 tentang Kepailitan dan Penundaan Kewajiban Pembayaran Utang (UUKPKPU) peranan Kejaksaan sebagai pemohon pailit diatur dalam ketentuan Pasal 2 ayat (2) yang menyatakan bahwa Kejaksaan dalam hukum kepailitan Indonesia demi kepentingan umum memiliki wewenang untuk mengajukan permohonan pailit terhadap Debitur yang memiliki utang terhadap dua orang Kreditor yang telah jatuh tempo dan dapat ditagih.

Tidak ada keharusan dari kantor pajak untuk memberikan wewenang kepada Kejaksaan sebagai pemohon pailit, karena pihak Debitur yang akan dimohonkan pailit bukanlah Debitur yang menurut regulasi kepailitan Indonesia merupakan Debitur yang permohonannya diwajibkan untuk dilakukan oleh lembaga tertentu sebagaimana diatur Pasal 2 ayat (3) UUKPKPU sampai dengan Pasal 2 ayat (5) UUKPKPU. Kantor pajak sebagai Kreditor dari Debitur yang memiliki utang pajak memiliki pilihan untuk memohon pailit dengan menggunakan jasa advokat atau menyerahkan kasus tersebut kepada Kejaksaan untuk dimohonkan pailit demi kepentingan umum. Keuntungan dari menyerahkan permohonan tersebut untuk diajukan oleh Kejaksaan adalah dari sisi biaya tidak akan memberatkan anggaran lembaga karena Kejaksaan tidak mengenakan biaya kepengacaraan (lawyer fee) hanya memerlukan biaya operasional dalam pengurusan perkara, biasanya advokat akan mengenakan biaya kepengacaraan tinggi karena walaupun prosedur beracara kepailitan singkat akan tetapi kepailitan adalah suatu perkara hukum yang mendetail serta memerlukan pemahaman teori dan praktik memadai yang tak semua advokat kuasai.

Akan tetapi dalam beracara secara formil Kejaksaan tidak dapat bertindak sebagai penerima kuasa yang bertindak untuk dan atas nama kantor pajak selaku Kreditor pemohon. UU Kepailitan dalam penjelasan Pasal 2 ayat 2 menjelaskan bahwa permohonan pailit dengan alasan untuk kepentingan umum baru dapat diajukan apabila ketentuan dalam Pasal 2 ayat (2) UUKPKPU telah terpenuhi dan tidak ada pihak yang mengajukan pailit. Unsur tidak adanya pihak yang mengajukan pailit tersebut tentu mengalami pertentangan dengan kuasa dari Negara yang diberikan kepada Kejaksaan untuk pengurusan perkara perdata dalam Pasal 30 ayat 2 UU Kejaksaan.

Di luar pertentangan redaksi Pasal-Pasal tersebut, wewenang jaksa untuk mewakili Negara dalam bidang perdata menemui titik temu dengan wewenang Kejaksaan untuk memohon pailit demi kepentingan umum.Titik temu tersebut adalah adanya kepentingan Negara yang harus diperjuangkan. Meski terdapat perbedaan bahwa untuk mewakili kepentingan Negara untuk memohon pailit Kejaksaan tidak diperlukan suatu kuasa khusus untuk mewakili Negara sebagaimana dapat 
ditafsirkan dari penjelasan Pasal 2 ayat (2) UUKPKPU, Kejaksaan tak sepenuhnya bergerak sendiri dalam kepailitan, kontribusi lembaga negara lain sebagai pihak yang langsung memiliki hubungan utang piutang dengan debitur juga diperlukan demi kelancaran permohonan pailit terhadap Debitur.

Adapun yang dimaksud dengan kepentingan umum menurut penjelasan Pasal 2 ayat (2) adalah kepentingan bangsa dan Negara dan/ atau kepentingan masyarakat luas. Menurut Peter Mahmud Marzuki ${ }^{12}$ kepentingan umum dapat diartikan sebagai kepentingan yang bukan merupakan kepentingan Kreditor ataupun pemegang saham. Kepentingan umum itu dapat saja masyarakat umum dalam pengguna jasa. Dalam hal yang sedang diajukan pailit itu adalah suatu perusahaan transportasi atau mungkin perusahaan yang mengolah bahanbahan perusahaan yang sedang dalam proses kepailitan lebih-lebih bila permohonan pailit itu diajukan oleh pihak Debitur. Sekalipun prosedur semuanya telah dilalui lengkap, hendaklah masalah kepentingan umum perlu menjadi pertimbangan.

Penjelasan Pasal 2 ayat (2) UUKPKPU tidak memberikan klasifikasi khusus mengenai apa yang dimaksud dengan kepentingan bangsa dan Negara dan/atau kepentingan masyarakat luas. Penjelasan Pasal 2 ayat (2) UUKPKPU memberikan contoh apa saja yang dapat dikategorikan sebagai kepentingan bangsa dan Negara dan/atau masyarakat luas, tetapi tidak bersifat terbatas terhadap contoh-contoh tersebut saja. Sifat tidak terbatas ini dilihat dengan pemilihan frasa misalnya, dibanding menggunakan frasa antara lain yang bersifat lebih mengikat. Beberapa contoh tersebut adalah:

1) Debitur melarikan diri;

2) Debitur menggelapkan bagian dari harta kekayaannya;

3) Debitur mempunyai utang kepada Badan Usaha Milik Negara atau badan usaha lain yang menghimpun dana dari masyarakat;

4) Debitur mempunyai utang yang berasal dari penghimpunan dana dari masyarakat luas;

5) Debitur tidak beritikad baik atau tidak kooperatif dalam menyelesaikan masalah utang piutang yang telah jatuh waktu; atau

6) Dalam hal lainnya menurut Kejaksaan merupakan kepentingan umum.

Mengajukan permohonan pailit terhadap Debitur WNA dengan adanya utang pajak yang belum terbayarkan dapat dikategorikan sebagai suatu permohonan pailit demi kepentingan umum, karena pajak merupakan salah satu dari sumber pendapatan negara dan juga mengingat penggunaan pajak untuk sebesar-besarnya kemakmuran rakyat, hal ini telah memenuhi unsur kepentingan bangsa dan Negara dalam kepentingan umum menurut penjelasan Pasal 2 ayat (2) UUKPKPU.

Selain terpenuhnya unsur kepentingan umum, hal lain yang perlu diperhatikan oleh Kejaksaan untuk dapat mengajukan permohonan pailit adalah ketentuan Pasal 2 ayat (1) UUKPKPU mengenai adanya dua orang Kreditor yang memiliki piutang terhadap Debitur yang belum dibayarkan serta telah jatuh waktu

12 Rahayu Hartini, Penyelesaian Sengketa Kepailitan di Indonesia, (Jakarta: Kencana, 2009), hlm. 82, dikutip dari Peter Mahmud Marzuki, "Hukum kepailitan Menyongsong Era Global" (makalah disampaikan pada semiloka "Restrukturisasi Organisasi Bisnis melalui Hukum Kepailitan”, FH. UNDIP-ELIPS, 1997). 
dan dapat ditagih. Sebagai pemohon pailit dengan dasar utang pajak Debitur terhadap negara maka tugas Kejaksaan harus menemukan paling sedikit satu utang yang belum dibayarkan Debitur terhadap seorang Kreditor lain untuk dapat memailitkan Debitur subyek hukum asing tersebut. Untuk memperoleh seorang Kreditor lain sebagai penyempurna syarat dua Kreditor maka Kejaksaan dapat menggunakan fungsi intelijen yang dimiliki oleh jaksa agung muda intelijen sebagaimana rumusan Pasal 16 huruf d Peraturan Presiden Nomor 38 Tahun 2010 tentang Organisasi dan Tata Kerja Kejaksaan yang menyatakan bahwa "dalam menyelenggarakan tugas dan wewenang sebagaimana dimaksud dalam Pasal 15, Jaksa Agung Muda Bidang Intelijen menyelenggarakan fungsi $\ldots d$ d. memberikan dukungan teknis secara intelijen kepada bidang-bidang lain di lingkungan Kejaksaan." Dukungan teknis dari Jaksa Agung Muda Intelijen tentu sangat membantu Jaksa Agung Muda Perdata dan Tata Usaha Negara untuk mengungkap utang-piutang yang dimiliki Debitur terhadap Kreditor lain di samping Negara guna memenuhi syarat adanya dua orang Kreditor.

Ketentuan utang dan jumlah minimum Kreditor merupakan aspek penting dalam hal melakukan permohonan kepailitan pada sistem peradilan Indonesia, dengan dipenuhinya utang yang telah jatuh tempo dan dapat ditagih dari Debitur serta jumlah minimal Kreditor telah tercapai maka pembuktian sederhana dalam persidangan pada pengadilan niaga akan lebih mudah, sehingga pengadilan memiliki kewajiban untuk mengabulkan permohonan pailit terhadap Debitur sebagaimana Pasal 8 ayat (4) UUKPKPU.

Apabila permohonan pernyataan pailit demi kepentingan umum dikabulkan oleh majelis
Hakim melalui suatu putusan pernyataan pailit yang diucapkan oleh majelis Hakim dalam persidangan di Pengadilan Niaga maka selanjutnya pengurusan dan pemberesan harta Debitur pailit dilakukan oleh Kurator untuk selanjutnya dipergunakan membayar piutangpiutang yang dimiliki oleh Kreditor-Kreditor yang berhak. Timbulnya wewenang pengurusan oleh Kurator menimbulkan Debitur demi hukum kehilangan haknya untuk menguasai dan mengurus harta kekayaannya yang dimasukkan dalam kepailitan.

\section{b. Pengurusan Harta Debitur Pailit di Luar Indonesia}

Redaksi Pasal 21 UUKPKPU menyatakan bahwa Kepailitan meliputi seluruh kekayaan Debitur pada saat putusan pernyataan pailit diucapkan serta segala sesuatu yang diperoleh selama kepailitan.Kedudukan Debitur sebagai subyek hukum yang berasal dari negara ASEAN non-Indonesia berimplikasi bahwa terdapat kemungkinan sebagian harta pailit berada di luar teritorial Indonesia. Setelah putusan dinyatakan pailitnya Debitur diucapkan oleh majelis Hakim, harta Debitur yang berada di luar Indonesia juga termasuk sebagai harta pailit, dan terhadap harta tersebut wajib diperhitungkan untuk melunasi utang yang dimiliki oleh Debitur terhadap Kreditor-Kreditornya. Dalam hal pengurusan harta pailit yang berada di luar yurisdiksi negara pemutus pailit dalam praktik peradilan kepailitan di negara-negara maju dikenal teori yang bernama cross border insolvency atau kepailitan lintas batas, suatu teori mengenai penyelesaian perkara kepailitan antara pihak Debitur dan Kreditor yang tunduk pada hukum nasional yang berbeda.

Kepailitan lintas batas tidak diatur secara komprehensif dalam UUKPKPU yang merupakan 
hukum positif Indonesia di bidang kepailitan yang saat ini berlaku.Ketidakkomprehensifan undang-undang kepailitan mengatur mengenai prinsip-prinsip kepailitan lintas batas (cross border insolvency) juga diakui oleh Jerry Hoff. Hoff mengatakan bahwa "unfortunately, the Bankruptcy Law does not deal with all of these matters. The bankruptcy law only deals with some issues of private international law. The other issues of cross border insolvency must be solved by the application of the rules of private international law or conflict law." ${ }^{13}$ Selanjutnya Hoff menyatakan bahwa sumber hukum utama untuk masalah-masalah hukum perdata internasional adalah perjanjian-perjanjian internasional (treaties), case law dan legal literature. Akan tetapi pada saat ini Republik Indonesia belum mengadakan perjanjian antar bangsa apa pun mengenai hukum perdata internasional berkaitan dengan cross border insolvency tersebut. ${ }^{14}$

Dalam hal penerapan kepailitan lintas batas Hadi Subhan ${ }^{15}$ berpendapat bahwa harus ada suatu traktat yang ditandatangani oleh Indonesia dan negara lain dan penandatanganan ini harus diratifikasi oleh DPR dalam rangka memberikan beban kewajiban pelaksanaan eksekusi putusan satu sama lain secara timbal balik (reciprocality) sebagaimana layaknya bila putusan dijatuhkan oleh pengadilan setempat. Indonesia sampai saat ini belum meratifikasi suatu perjanjian internasional di bidang kepailitan lintas batas, dan juga belum membuat suatu kesepakatan bilateral dengan negara manapun dalam hal tersebut. Indonesia bukan pihak penandatangan atas traktat internasional sehubungan hal-hal kepailitan internasional seperti halnya traktat mengenai UNCITRAL Model Law on Cross Border Insolvency. Untuk itu proses pengurusan harta pailit oleh Kurator hanya mengandalkan pandangan hukum nasional dari negara tempat harta tersebut berada terhadap pelaksanaan putusan pailit negara asing.

Praktik pengakuan putusan pengadilan asing termasuk putusan tentang kepailitan berbedabeda di masing-masing Negara ASEAN ${ }^{16}$. Sistem hukum Filipina mengatur bahwa pengadilan Filipina tidak mengakui sama sekali putusan pengadilan kepailitan asing. Vietnam mengatur ketentuan yang lebih fleksibel dimana pada dasarnya pengadilan Vietnam tidak mengakui putusan pengadilan asing namun putusan pengadilan asing dapat diakui di Vietnam dalam hal Negara asing tersebut menandatangani perjanjian bilateral dengan Vietnam terkait dengan pengakuan dan pelaksanaan putusan pengadilan asing atau Negara asing tersebut merupakan co-signatory sebuah international treaty terkait dengan pengakuan dan pelaksanaan putusan pengadilan pengadilan asing dimana Vietnam juga terikat dengan perjanjian internasional tersebut. Sistem hukum Indonesia mengatur bahwa hukum Indonesia tidak mengakui proses kepailitan yang

13 Hadi Shubhan, Op. cit., hlm. 98, dikutip dari Jerry hoff, Indonesian Bankruptcy Law, (Jakarta: Tatanusa, 1999), hlm. 193.

14 Ibid, dikutip dari Jerry Hoff, Op. cit., hlm. 194.

15 Ibid, hlm. 98-99.

16 Rosalia Suci et al., " Aspek Hukum Kepailitan dan Insolvensi Bank di Negara-Negara ASEAN”, Buletin Hukum Perbankan dan Kebanksentralan Bank Indonesia Volume 9, Nomor 3 (2011), http://www.bi.go.id/id/publikasi/ lain/hukum-perbankan/Documents/306fa54942ca4b44a469346e28f16294BuletinHukum09091211.pdf (diakses 17 Mei 2014). 
dilakukan di Negara asing kecuali apabila Negara asing tersebut menandatangani perjanjian bilateral dengan Indonesia atau Negara asing tersebut dan Indonesia terikat dalam suatu perjanjian internasional mengenai pengakuan dan pelaksanaan putusan pengadilan asing. Singapura memiliki sitem hukum yang berbeda dimana pengadilan singapura mengakui putusan pengadilan asing terkait dengan kepailitan suatu institusi yang didirikan di Negara asing tersebut. Demikian pula Malaysia mengakui proses kepailitan dan putusan pengadilan asing yang dilakukan di luar wilayah yurisdiksi Malaysia walaupun dalam prakteknya pelaksanaan putusan pengadilan asing tersebut tidak mudah karena biasanya the High Court Malaysia akan menunjuk likuidator lokal untuk menjual asetaset Debitur yang berada di Malaysia dan kemudian membayarkan hasil penjualan asetaset tersebut kepada likuidator asing setelah dikurangi dengan kewajiban-kewajiban Debitur kepada Kreditor lokal Malaysia. Hukum Thailand tidak mengakui proses peradilan insolvensi yang dilakukan di luar wilayah kerajaan Thailand termasuk juga tidak memberikan akses kepada Kurator asing untuk turut serta dalam proses kepailitan di Thailand. Kurator asing harus terlebih dahulu melakukan gugatan ke pengadilan untuk meminta pembayaran atas utang-utang tersebut.

Dari data pelaksanaan putusan asing pada beberapa negara ASEAN di atas dapat kita lihat bahwa beberapa negara seperti Singapura, Malaysia dan Vietnam (dengan catatan telah ditandatanganinya perjanjian dengan Vietnam) menerapkan prinsip universal untuk mengakui keberadaan putusan asing dan pelaksanaan putusan tersebut di negaranya, negara lain seperti Thailand dan Filipina secara tegas menyatakan tidak mengakui putusan kepailitan asing atau dapat disimpulkan menerapkan prinsip teritorial dalam hukum kepailitan nasionalnya. Apabila terdapat perbenturan antara prinsip universaldengan prinsip teritorial, maka yang akan dipakai adalah prinsip teritorial. Hal ini karena kedaulatan suatu Negara akan berada di atas kekuatan hukum mana pun dan pendekatan asli dari suatu cross border insolvency adalah prinsip teritorial. Prinsip teritorial akan dikesampingkan apabila terdapat kesepakatan-kesepakatan

internasional (treaties) atau suatu Negara tersebut samasama menganut prinsip universal. Pada dimensi lain, bisa diupayakan dengan jalan mengajukan permohonan pailit ke beberapa Negara yang terdapat harta Debitur tersebut. ${ }^{17}$

Selama belum disepakatinya perjanjian bilateral antar negara-negara ASEAN atau perjanjian Multilateral yang menaungi seluruh negara ASEAN dalam hal kepailitan maka proses pengurusan harta Debitur pailit akan tetap menemui kendala, terutama pada negara-negara yang tak mengakui putusan pailit negara asing terhadap aset yang berada dalam wilayah negaranya. Kasus seperti tidak diakuinya wewenang Kurator asing untuk melakukan pengurusan harta Debitur pailit di negara tempat aset berada serta tidak diakuinya putusan pailit pengadilan Indonesia oleh pihak yang berwenang di negara ASEAN lainnya tempat harta Debitur tersebut berada masih akan jamak terjadi.

7 Hadi Shubhan, Op.cit., hlm. 49. 


\section{Penutup}

Utang pajak dapat dikategorikan sebagai utang dalam kepailitan, karena memenuhi unsur-unsur utang yang dimaksud dalam hukum kepailitan Indonesia, dan sengketa utang piutang dalam perpajakan yang memposisikan negara sebagai Kreditor dan subyek hukum dari negara ASEAN non-Indonesia sebagai Debitur dapat diselesaikan melalui prosedur kepailitan Indonesia dengan menerapkan konsep kedaulatan teritorial karena utang piutang pajak terjadi dalam yurisdiksi Indonesia.

Kejaksaan dengan alasan untuk kepentingan umum dapat mengajukan permohonan pailit terhadap Debitur subyek hukum dari negara ASEAN non-Indonesia pada Pengadilan Niaga karena kepentingan negara merupakan salah satu penjabaran dari kepentingan umum yang dapat dimohonkan pailit, dengan catatan bahwa kejaksaan dalam proses beracara dalam hal permohonan pailit tidak mewakili lembaga yang berwenang di bidang perpajakan karena UUK mengamanatkan bahwa permohonan pailit demi kepentingan umum baru dapat dilakukan apabila tidak ada pihak yang mengajukan permohonan pailit. Walaupun tidak mewakili lembaga yang berwenang di bidang perpajakan tetapi kejaksaan tetap dapat berkoordinasi dengan lembaga tersebut mengingat tujuan yang sama untuk mengembalikan piutang pajak negara.

Ketentuan yang menyatakan permohonan pailit untuk kepentingan umum hanya dapat dilakukan apabila tidak ada pihak yang mengajukan permohonan pailit sebaiknya diberikan pengecualian oleh pembuat undangundang, dalam hal kejaksaan memohon pailit untuk kepentingan umum yang menyangkut kepentingan negara kejaksaan sebaiknya diberi wewenang untuk bertindak mewakili atau sebagai kuasa dari lembaga negara yang secara langsung memiliki utang piutang terhadap Debitur, agar lembaga yang secara langsung memiliki hubungan utang piutang terhadap Debitur tidak menganggap kejaksaan bekerja secara mandiri tanpa mengindahkan kepentingan dari lembaga tersebut.

Pemerintah Indonesia diharapkan untuk segera menyepakati perjanjian internasional yang ada dalam hal kepailitan lintas batas (cross border insolvency) atau menyepakati perjanjian bilateral maupun multilateral mengenai kepailitan lintas batas di regional ASEAN karena integrasi ekonomi dalam AEC juga sebaiknya diikuti dengan integrasi instrument hukum kepailitan antar negara anggota agar prosedur peradilan kepailitan antara negara-negara anggota ASEAN lebih efektif dan efisien serta mendapat pengakuan dan sifat mengikat pada seluruh hukum nasional negara anggota ASEAN.

\section{DAFTAR PUSTAKA}

\section{Buku}

Ekawati, Evy Lusia, Peranan Jaksa Pengacara Negara dalam Penanganan Perkara Perdata, (Yogyakarta: Genta Press, 2013).

Hartini,Rahayu, Penyelesaian Sengketa Kepailitan di Indonesia, (Jakarta: Kencana, 2009).

Saleh, Abdul Rahman, Bukan Kampung Maling, Bukan Desa Ustadz, (Jakarta: Kompas Media Nusantara, 2008).

Shubhan, Hadi, Hukum Kepailitan, Prinsip, Norma, dan Praktik di Pengadilan, (Jakarta: Kencana, 2009).

Starke, J.G, Pengantar Hukum Internasional 1, (Jakarta: Sinar Grafika, 2010).

\section{Internet}

ASEAN Secretariat, "ASEAN Economic Community Blueprint", (Jakarta, 2008), www.asean.org/ archive/5187-10.pdf (diakses 9 Mei 2014).

Badan Koordinasi Penanaman Modal, "Avoidance of Double Taxation Agreement", Badan Koordinasi Penanaman Modal, http://www3.bkpm.go.id/ 
contents/p14/taxation/14\#.U5fE9PI_tQF (diakses 10 Juni 2014).

Departemen Perdagangan Republik Indonesia,"Menuju ASEAN Economic Community 2015",http://ditjenkpi.kemendag. go.id/website_kpi/Umum/Setditjen/Buku\%20 Menuju\%20ASEAN\%20ECONOMIC\% 20 COMMUNITY\%202015.pdf (diakses 9 Mei 2014).

Rosalia Suci et al., "Aspek Hukum Kepailitan dan Insolvensi Bank di Negara-Negara ASEAN", Buletin Hukum Perbankan dan Kebanksentralan Bank Indonesia Volume 9, Nomor 3 (2011), http://www.bi.go.id/id/publikasi/lain/hukumperbankan/Documents/44a469346e28f1629 4BuletinHukum09091211.pdf (diakses 17 Mei 2014).

\section{Peraturan perundang-undangan :}

Kitab Undang-Undang Hukum Perdata, Staatsblad 1847 Nomor 23.
Undang-Undang Nomor 8 Tahun 1983 tentang Ketentuan Umum dan Tata Cara Perpajakan sebagaimana perubahan terakhir dalam Undang-Undang Nomor 28 Tahun 2007.

Undang-Undang Penagihan Pajak dengan Surat Paksa Nomor 19 Tahun 1997 dan perubahannya dalam Undang-Undang Nomor 19 Tahun 2000.

Undang-Undang Nomor 14 Tahun 2002 tentang Pengadilan Pajak.

Undang-Undang Nomor 16 Tahun 2004 tentang Kejaksaan Republik Indonesia.

Undang-Undang Nomor 37 Tahun 2004 tentang Kepailitan dan Penundaan Kewajiban Pembayaran Utang.

Undang-Undang Nomor 23 Tahun 2013 tentang Anggaran Pendapatan dan Belanja Negara Tahun Anggaran 2014.

Peraturan Presiden Nomor 38 Tahun 2010 tentang Organisasi dan Tata Kerja Kejaksaan. 